\title{
THE LEGAL STATUS OF MUT'AH MARRIAGE IN INDONESIA
}

\author{
Mimin Mintarsih*, Lukman Mahdami* \\ *Fakultas Hukum, Universitas Islam Jakarta, Jakarta \\ Corresponding email: miminmintarsih@uid.ac.id \\ Paper received on: 14-07-2021; Revised on: 19-08-2021; Approved to be published on: 03-09-2021 \\ DOI: http://dx.doi.org/10.30641/dejure.2021.V21.397-408
}

\begin{abstract}
Mut'ah marriages with contract marriages bring a dilemma to society. The society views that this is halal (lawful) and legal, but in essence it does not carry out rights and obligations. The problem of this paper is how do civil cases (of mut'ah marriage) get legal certainty so that the logic of "urgent" becomes a status that can protect the rights and dignity of married couples in Indonesia? The purpose of this paper is to analyze the status of mut'ah marriage law so that it does not become a political contribution in Indonesia. The research method used is normative juridical. The result of this research is that in relation to the basis for practice of mut'ah which is considered an emergency, it is clearly contrary to Islamic law because the real aim and purpose of marriage are permanent. Mut'ah actually destroys human civilization and ethics or implies bad faith. The harm will befall the offspring. Children who are born have no legal certainty because they are considered children born of adultery. This research concludes that mut'ah is contrary to the basic provisions of the Material Law of the Religious Courts on Marriage which strictly prohibits mut'ah marriages (Article 2 paragraph 2 of Law No. 1 Year 1974 concerning marriage), the criminal sanctions are regulated in the Draft Law on the Religious Courts of Marriage Article 39 because it is not recorded and Article 144 concerning sanctions against the perpetrator, and the marriage is null and void by law.
\end{abstract}

Keywords: mut'ah marriage; status; marriage law

\section{INTRODUCTION}

Humans are creatures who live in pairs with rules and marriage is not only for having sexual intercourse with the opposite sex, but also for achieving happiness.

Relationships of the opposite sex have always been part of the necessities of life (sunnatullah). With the rules of marriage, human dignity remains respected and the children born of marriages are legal, both according to their religion and according to applicable laws and regulations.

Marriage in Islamic teachings provides the right space as a civilized being so that marriage is also a very special and measurable concern as a noble award for those who are able to subdue it (syahwat). In the Compilation of Islamic Law, the akad (covenant) in marriage is one of worship for humans in order to obey the commands of Allah SWT $^{1}$.

The rapid development of medical technology for the sake of human regeneration has

Nurlailiyah Aidatussholihah, "Kawin Kontrak di Kawasan Puncak : Antara Normatif, Yuridis, dan Realita," Jurnal Al-Ahwal 5, no. 2 (2012): 3. made the problem of marriage possible through insemination or tube technology, which has become commonplace. However, promiscuity is one of the sexual deviations caused by the environment and even the effect of rapid development of audiovisual technology in the form of movies or images that display sexuality. These things can be enjoyed by all people so that it becomes a determining factor for sexual freedom. So far, the solution has not been able to prevent sexual deviations from occurring.

Linguistically, for the layman, the term kawin (marriage) or nikah (marriage) has been seen as a reflection of religion. However, other efforts in certain circles try to keep the rules seen as religious, but the essence of the marriage is not like that. This is to make it look like a legal contract marriage or mut'ah in order to refine the purpose of marriage so that it looks like an Islamic marriage.

Mut'ah marriage is ironically done by certain circles of Muslims in Indonesia so that they try to package it in Islamic teachings so that it becomes legal. This is even done deliberately and even 
though it is only for a certain time and produces quite fantastic economic value.

Young adults, such as students or college students, who are able to practice contract marriage or mut'ah have an impact on disturbing parents. In fact, scholars, educators, and community leaders realize that this will facilitate the development of Shia teachings in Indonesia.

The problem that arises is that the bride and groom have agreed on the needs of sex and the economic side as well as the time limit for the marriage. If the marriage is completed after the time limit expires, the marriage is no longer the responsibility of the parties. The marriage vows show that the mut'ah marriages doers have directly determined the time of talak (divorce) in their ijab qabul (covenant) without having to go through the divorce process in general.

The state of Iran is based on the Ja'fari madhhab (school of thought) of twelve imams (article 12) ${ }^{2}$ which is a branch of the Shia Imamiyah teachings. The practice of sigheh (temporary marriage) is said to have existed during the life time of Prophet Muhammad, who is believed to have recommended it to his companions and soldiers. Sigheh (Persian) or mut'ah is a belief because it is part of his teachings that must be believed in. Sayid Sabiq says that it is only because it fulfils pleasure or determined time, so it is known by Shia fuqaha as a small covenant. In the pillars, nothing is violated because all requirements of marriage are generally met.

According to the majority of scholars among the Sunni Ahlu Sunnah, mut'ah marriage is already forbidden to be done. However, other opinions such as (Zufar from the companions) the Hanafi group state that marriage cannot be cancelled only because there are conditions that cancel it or it has to go through a divorce process where the talak is pronounced. Ibn Hajar al-'Asqalaniy as narrated by Muhammad Jawad Mughniyah states that several authentic hadiths expressly prohibit mut'ah marriages which had previously been permitted.

The views of the companions such as Ibn Umar, Ibn Abi Umrah al-Anshari, and from the

\footnotetext{
Humas Kedutaan Besar Republik Islam Iran, UndangUndang Dasar Republik Islam Iran (Terjemahan) (Jakarta Pusat: Kedutaan Besar Republik Islam Iran, 1989), 12.
}

fuqaha namely Abu Hanifah, Malik, al-Syafi'i, Ahmad Ibn Hambal, state that the prohibition of mut'ah marriage is absolute ${ }^{3}$. The reasons for the prohibition of mut'ah marriage are as follows 4 :

First, this kind of marriage is not in accordance with sharia, especially in the matter of talak (divorce), 'iddah and heirloom/will. Therefore, marriage like this is unlawful like other forms of marriage that are forbidden in Islam.

Second, it is clear that mut'ah is forbidden. According to Saburah Al-Jahmiy where he once accompanied the Messenger of Allah in the war to conquer Mecca, he said that he did not leave this mut'ah marriage until it was forbidden from Rasulullah's mouth (conveyed verbally) forever.

Third, Caliph Umar bin Khatab RA in his pulpit has forbidden mut'ah marriage where the companions also agreed to the prohibition of mut'ah marriage because it is wrong.

Fourth, Al-Khatthabi says: 'The prohibition of Mut'ah marriage is ijma'. From Rafidhah, mut'ah is disputed because there is no valid basis. In fact, there is a valid narration from 'Ali that the permission of mut' ah marriage has been abolished which was conveyed through the mouth of the Rasulullah forever. Al-Baihaqi narrated from Ja'far bin Muhammad when he was asked about mut'ah marriage, he replied that it was tantamount to adultery. The objective of mut'ah marriage is just for fun and it can harm women, because they are like an object that is transferred from one hand to another. Women, in mut'ah marriages, do not get a decent material life like a house to live in and get a good education.

The Shia madhhab allows mut'ah marriage because this madhhab considers that there is no authentic Prophet hadith where there is a prohibition on mut'ah marriage. They consider that mut'ah marriage is already an ijma (consensus) of ulama (Muslim scholars) and is a common belief. Shia alshadiq state that the verse about mut'ah was not revoked (not at all).

In the book Bidayah Almujtahid, Ibn Rushd mentions mutawatir about the prohibition of mut'ah marriage during the war in Khaibar, the

\footnotetext{
3 Chuzaimah T Yanggo dan Hafiz Anshari, Problematika Hukum Islam Kontemporer (Jilid I) (Jakarta: PT. Pustaka Firdaus, 1996), 85.

4 Sayyid Sabiq, Fikih Sunnah (Jilid 6) Terj. Mohammad Thalib (Bandung: PT. al-Ma'arif, 1980), 63.
} 
events of fath Mecca, the year of hajj wada', the year of 'Umrah qadha' and the events of the authas war'.

The equivalent of mut'ah marriage with contract marriage brings a dilemma to society, especially in some areas where the procedure is made like marriage in Islamic teachings. The general public considers this to be lawful and legal, but in essence it does not carry out the rights and obligations as a household referred to in Islamic teachings and legislation.

Sexual deviation which is called mut'ah marriage or contract marriage which is also driven by religious leaders around it is considered by the surrounding community, especially in the Blitar, Central Java, and Bogor areas, becoming a topic of discussion which is full of controversy among Muslim scholars and academicians in Indonesia ${ }^{6}$.

M. Quraish Shihab states that what has been discussed in various circles from the past until now is whether mut'ah marriage is lawful or unlawful' ${ }^{7}$. The opinion that allows mut'ah marriage states that it is something that can be accepted because it is a very urgent need, or emergency. This does not mean that the change of partners can be done by anyone, any time, and with any woman. It should also be remembered for those who want to perform a mut'ah marriage that the woman to be married must be a respectable woman.

In the past, mut'ah was carried out for men who were married and in the battlefield because sexual libido had a very large impact, especially on psychological things. This does not consider age, especially for men who have a strong desire to have sex or intimate relationships like husband and wife. If it is not fulfilled, this has the side effect of being unmotivated, frustrated or depressed and even tends to be temperamental (uncontrolled emotions). So, the "urgent" emergency limit said by Quraish Shihab is more likely to change partners as desired. In fact, if mut'ah is performed, it only answers certain conditions and situations. This is viewed solely because the libido of men in wartime

5 Ibnu Rusyd Al-Hafid, Bidayat al-Mujtahid wa Nihayah al-Muqtashid (terjemahan) (Juz I) (Kairo: Maktabah Dar al-Salam, 1999), 187.

6 M. Quraish Shihab, Perempuan dari Cinta Sampai Seks, dari Nikah Mut'ah Sampai Nikah Sunnah, dari Bias Lama sampai Bias Baru (Jakarta: Lentera Hati, 2016), 187.

7 Ibid., 204. affects mainly his psyche. If this desire is fulfilled, then the man does not experience a weakness in his fighting strength or fighting spirit. Based on this, mut'ah marriage is not the answer. In fact, the mut'ah marriage did not pay attention to the post-war effects the men faced. There has never been a recommendation for mut'ah marriage. This actually destroys the historical value that tends to darken the polygamy verse.

According to the opinion of Quraish Shihab from maqâsid dharûriyyat, mut'ah is paired with polygamy which is basically categorized as maintaining religion (hifz al-dîn). His opinion is considered to loosen a prohibition to much in the name of the word "urgent" or "emergency". In fact, many men who performed mut'ah marriage always use "urgent" or "emergency" reasons which lead to form an absolute justification pattern and shift the prohibited elements of mut'ah marriage.

Mut'ah in Indonesia is very interesting to study because it is motivated by political elements. This is considered a prostitution emergency so that it is urgent to get a legal answer to become a legal marriage. The problem is how do civil cases (mut'ah marriage) get legal certainty with the "urgent" logic so that it can protect the rights and dignity of mut'ah marriage doers in Indonesia?

The purpose of this research is to analyze the legal status of mut'ah marriage, especially the mut'ah problem that developed in several regions so that it does not become a political contribution in Indonesia. The function of this paper is to provide information on the legal status of mut'ah marriages that have a broad impact on the Indonesian Muslim community.

\section{RESEARCH METHOD}

The research method used is a normative legal research method which used references on literature, library materials and applicable legal regulations as data sources (library research). Then, the analysis was carried out by interpreting the data, the applicable legal bases, and the opinions of experts. 


\section{DISCUSSION AND ANALYSIS}

\section{A. The Definition of Mut'ah Marriage}

Marriage as a marriage covenant is mentioned in the compilation of Islamic law $^{8}$ article 1 letter c which states that marriage covenant is a series of ijab (statement to handover) pronounced by the guardian and kabul (statement to accept) which is pronounced by the groom or his representative witnessed by two witnesses. The covenant as referred to in the compilation of Islamic law is the basis for marriage. In article 2, marriage according to the book Compilation of Islamic Law is a very strong covenant or mistaqan ghalizan to obey Allah's commands and carrying it out is an act of worship.

In the Qur'an, there are two keywords that indicate the concept of marriage, namely zawwaja جوز (20 verses) and the word nakaha حكن (approximately 17 verses). In the context of the marriage bond (aqad), which is commonly referred to as حاكن and قاثثيم, this is mentioned as an agreement stated in the QS. An-Nisa'; 3 and An-Nur; 32 and with the word mitsaq in QS. An-Nisa'; 21. Some people interpreted marriage as قطاحم ittifaq (agreement) and تطناماض mukhalathat (mixture), and some interpret "dham" (flanking), or "squeezing". Meanwhile, the figurative meaning of marriage means "wathaa" (intercourse) or "aqad" (conducting a marriage agreement). The word which is commonly used is the word marriage (nikah).

In the Indonesian Dictionary it is stated that the meaning of perkawinan is the same as the meaning of pernikahan, because the word perkawinan derives from the word "kawin" which means "nikah." This word is the mashdar form of the word "Nakaha-yankihu-nikah" (which originally means "to have intercourse" and "to gather"). The opinion of some Fiqh scholars, who give the basic meaning of the word "nikah" with the same meaning and add it with the meaning of "inserting", is used in the sense of "having intercourse".

Mut'ah marriages performed by both men and women only fulfill the desire for sexual pleasure where some people who do it make this a side job. This marriage is actually similar

8 Tim Redaksi Nuansa Aulia, Kompilasi Hukum Islam Ed. Lengkap (Bandung: Nuansa Aulia, 2020), 1. to buying and selling that leads to a circle of prostitution. Men and women who do it by means of mut'ah marriage are essentially just to satisfy their lust, "it's just fun at that time". In addition, mut'ah is a great opportunity for the couples to commit adultery in the name of religion.

\section{B. The Motivations for Mut'ah Marriage}

Sourced from Jabir bin Abdullah, the prophet said, "A woman (seen) from the front is always seductive, from behind too. If a man is tempted by a woman, then come (channel it to) his wife, because it will be able to pacify his soul." (Narrated by Muslim, Abu Dawud, and at-Tirmizi $)^{9}$.

The sexual instinct for humans as perfect beings on this earth is channelled through marriage to justify sexual intercourse between men and women. It is marriage that keeps them away from worries and negative effects, and He has placed between you compassion and mercy. Surely in this are signs for people who reflect. (QS. Ar-Rum: 21).

The motivation of women to marry by mut'ah marriage is caused by the high sex drive and motivation to try to legalize adultery, psychological protection, love and affection, in addition to fulfilling economic needs. After channelling their pleasure, the marriage will produce mere sexual satisfaction. However, women's self-perception in conducting self-evaluation after undergoing a mut'ah marriage in general tends to be considered negative.

\section{The Problems of Mut'ah Marriage}

Mut'ah marriage, even though its implementation has a sîghah (utterance) of ijab and kabul using the lafaz zawwajtuka, unkihuka or matta'tuka (I marry you temporarily), is carried out without a guardian, without witnesses. The time limit agreed upon by both (prospective husband and prospective wife) is also stated and it will end by itself without khuluk or thalaq, and the dowry agreed upon by both parties is stated ${ }^{10}$. If a child is born from this marriage, the child's

9 Muhammad bin Isa bin Saurah At-Tirmidzi, Hadis No. 1024 dalam CD program Mausu'ah Hadis al-Syarif (Riyad: VCR II Global Islamic Software Company, 1997). 1.

1o Sachiko Murata, Temporary Marriage in Islamic Law (Terjemahan Tro Wibowo Budi Santoso: Lebih Jelas Tentang Mut'ah Perdebatan Sunni dan Syi'ah (Jakarta: PT. Raja Grafindo Persada, 2001), 44-50. 
position is the same as that of a child born in a permanent marriage, but it is more likely that the couple just enjoys sex or uses contraception. There is no right of inheritance between husband and wife, there is no 'Iddah period and there is no 'iddah sustenance. In fact, this violates sharia even though they are still legally married.

Mut'ah marriage does not mention the prohibition for women to remain staying with only one man. Whereas what generally happens is that women can be enjoyed by other men while they are still bound in mut'ah marriage, because the marriage aims only to achieve their needs.

The provisions of mutah marriage have differences with the provisions of daim (permanent) marriage such as the time limit set on the pillars of mut'ah marriage. Daim marriage has no time limit and agreements. Mut'ah marriage also does not stipulate witnesses as pillar in marriage

The pillars and conditions in mut'ah marriage are, among others, Ijab Kabul, time limit, dowry and the presence of the prospective husband and the prospective wife ${ }^{11}$.

\section{The Opinions of Religious Leaders in Indonesia}

In the matter of marriage, fiqh experts interpret marriage according to the figurative meaning. They differ on the figurative meaning they use. Abu Hanifah uses the meaning "intercourse". Meanwhile, al-Syafi' $i$ uses the meaning "to enter into an engagement agreement." When viewed from the point of view of the existence of legal certainty and the use of the word "marriage" in the Qur'an and the Prophet's hadiths, "marriage" with the meaning "engagement agreement" is more appropriate and widely used than "marriage" with the meaning of "intercourse". Ibn Jinni ${ }^{12}$ once asked Abu Ali about the meaning of their words nakaha al-mar'ah حكن ةأرملا, he answered: “The Arabs use the word nakaha in different contexts, so that the meaning can be separated subtly, so as not to cause confusion. If it is said nakaha fulan fulanah, then what is meant is that he (man) enters into marriage bond with a woman. When it is

"Ali Akhbar Abaib Mas Rabbani Lubis, "NIKAH MUTAH: Melirik Pergumulan Sejarah, Firman, Sabda, dan Nalar Nikah Mutah," Jurnal Universum 14, no. 1 (2020): 6 .

12 Karnal Muchtar, Asas-Asas Hukum Islam Tentang Perkawinan (Jakarta: Bulan Bintang, 1996), 1. said nakaha imraatahu, then what is meant is the intercourse."

Ali al-Shabuniy said that what is meant by marriage is a marriage bond, not mere intercourse. Therefore, it is never mentioned in the Qur'an about the word marriage with the meaning wati ' طو. The Qur'an uses the word kinayah. Some definitions of marriage among Fiqh scholars are slightly different, but the essence is the same.

Scholars of the Shafi'i Madhhab define marriage as a covenant that contains the legitimation of sexual intercourse. Given the pronunciation is nikah/kawin, then the meaning is still the same, namely the sexual intercourse/jima. Meanwhile, the scholars Hanafi Madhhab define marriage as a covenant that provides the benefits of having a lawful sexual intercourse between a husband and a wife as long as there are no sharia obstacles ${ }^{13}$.

The definition from the majority of the scholars emphasizes the importance of mentioning the pronunciation of marriage in the covenant. In the definition from the Hanafi madhhab, all pronunciations that contain the meaning of the legitimation of a man and a woman having sexual intercourse may be used, such as the pronunciation of hibah (grants) as long as there are no sharia obstacles to marrying the woman. For example, the woman is not a mahram (forbidden to marry/ blood relations) and is not an idol worshipper, so according to the majority of scholars, it is sufficient to discuss in the terms of marriage ${ }^{14}$.

Even then marriage basically maintains maternal instincts and the identity of a father. In addition, a marriage also contains: (1) Channeling sexual instincts legally and properly, (2) The best way to get children and develop offspring legally, (3) Cultivating a sense of responsibility in the context of nurturing and educating children so as to provide a strong motivation for a person to make the people he/she is responsible for happy, (4) Dividing responsibilities between husband and wife, which so far may only be borne by each party, (5) Uniting the two big families so that the relationship is getting stronger. Therefore, more

13 Syaikh Muhammad al-Syarbini Al-khatib, al-Iqna (Juz II) (Beirut: Dar al-Fikr, 2005), 409.

14 Al-Hafid, Bidayat al-Mujtahid wa Nihayah alMuqtashid (terjemahan) (Juz I) (Kairo: Dar al-Salam), 665. 
new families will be formed, and (6) Extending life $\mathrm{e}^{15}$.

Yusuf Qardhawi defines mut'ah marriage because there is a certain time limit and wages. According to Ibrahim Muhammad al-Jamal, mut'ah marriages or marriages that are interrupted, are stated in the covenant for a matter of days or certain agreed period of time. In mut'ah marriage, what happens is that one is more likely to be able to enjoy sex to his heart's content as specified in the covenant. According to Muhammad Fu'ad Shakir, the word mut'ah (متعلا) means having fun with women, but not forever. Al-Azhari argues that " $a l$ Mataa' 'u" (عاتملا) means anything that is useful for oneself only. According to M. Quraish Shihab, the word mut>ah has several meanings, including benefits, having fun, enjoying, provisions and others.

\section{B. The Legal Status of Mut'ah Marriage in Indonesia}

Sayuti Talib says that marriage is a promise between a man and a woman to form a family community in a legal and lawful bond ${ }^{16}$. Zahry Hamid states that marriage is a covenant (ijab qabul) between the guardian of the prospective wife and the groom with certain utterances and fulfills the pillars and conditions ${ }^{17}$.

If the ones who say the covenant do not seriously intend to realize the marital relationship, do not understand the purpose of the covenant, and is not aware in saying it, the ijab qabul or covenant in mut'ah marriage becomes invalid. Covenant in mut'ah marriage is also invalid if it uses the sentence "I own" (mallaktu), "I give" (wahabtu), or "I rent" (ajjartu). However, a mut'ah covenant is considered valid if it uses various languages that have meanings that are understood and accepted by both parties. Mut'ah marriages are accepted or valid even though they only use qabul sentences in the form of short statements such as "I accept" (qobiltu) or "I am willing" (rodhitu $)^{18}$.

15 Ibid., 665 .

16 Sayuti Thalib, Hukum Kekeluargaan Indonesia (Cet. 5) (Jakarta: UI Press, 1978), 47.

${ }_{17}$ Zahry Hamid, Pokok-Pokok Hukum Perkawinan Islam dan Undang-Undang Perkawinan di Indonesia (Yogyakarta: Bina Cipta, 1978), 1.

18 Muhammad Anis Malik, "Wawasan Hadis Tentang Nikah Mut'ah (Suatu Kajian Mawudhu'iy)," Jurnal AlMaiyyah 8, no. 2 (2015): 285.
Sheikh Kamil Muhammad Uwaidah states that the word marriage means union or intercourse (sex) or mixing. This is said as marriage in general. However, in the development of the next era, there are more developments in thought, especially regarding the technical aspects of marriage, so as to exclude the norms of sharia that are Sunni, like the teachings of Shia which legalize mut'ah marriage.

Indonesia's population is predominantly Sunni Muslim. Shia teachings are similar to Islamic teachings that mut'ah marriage has never been banned. There are many deviations of opinion about mut'ah marriage which is quite widespread in Indonesia. The controversy regarding mut'ah marriage is still a fundamental polemic.

Muhammad Fu'ad Syakir is of the opinion that mut'ah marriage (تعنمل) is carried out with the dowry agreed by both parties and at the same time determining the time (period) for the end of the marriage ${ }^{19}$. When the promise ends, mut'ah marriage ends without pronouncing talak and there is no iddah period. Sayyid Sabiq says that mut'ah marriages are terminated marriages because men marrying women are limited by the agreed time ${ }^{20}$. Even though the prohibition on mut'ah marriage was conveyed mutawatir, but what became a dispute was the legitimation of mut'ah marriages that occurred during the Khaibar war.

The mut'ah marriage covenant determines the time limit (end) according to the agreed amount of dowry. In fact, the basic purpose is only sexual enjoyment and the couples do not intend to give birth to offspring and even there is no inheritance right between husband and wife. In this case, the covenant is the right place to cheat on the rules in an effort to avoid the law or sharia because so far it is considered to be the pillars. In Shia teachings, mut'ah marriage has "pillars" and "laws" 21. In the Encyclopedia of Islamic $\mathrm{Law}^{22}$, it is stated that the conditions for mut'ah marriage according to Shia scholars are puberty, reason, and there are no obstacles to carry it out such as kinship ties, breast-feeding

\footnotetext{
19 Muhammad Fu'ad Syakir, Zawajun Bathil: al-Misyar, al-Urfi, as-Sirri, al-Mut'ah, Terj. Fauzun Jamal dan Alimin, "Nikah Terlarang: al-Misyar, al-Urfi, as-Sirri, al-Mut'ah" (Jakarta: CV. Cendikia Sentra Muslim, 2002), 65.

20 Sayyid Sabiq, Fiqh al-Sunnah (Juz II) (Kairo: Maktabah Dar al-Turas, 1970), 130.

${ }_{21}$ Sachiko Op.Cit, 44-6o.

${ }^{22}$ Abdul Aziz Dahlan dan dkk, Ensiklopedia Hukum Islam (Jilid IV) (Jakarta: Ichtiar Baru Van Hoeve, 1996), 1346.
} 
siblings or still being someone else's wife. The provisions regulated in their teachings are to marry a good woman, the time limit must be determined when the covenant takes place and if necessary, it must be adjusted to the dowry agreement. Furthermore, if the mut'ah marriage period ends, then the marriage is terminated without thalaq or khuluk and the husband and wife do not inherit from each other. The practice is based on looking for justification in the $u s l u b$ (language style) of the Qur'an Q.S. An-Nisa verse 24 " ... as an obligation. And there is no blame upon you for what you mutually agree to beyond the obligation." Therefore, the direction of mut'ah marriage is actually made in such a way that it looks halal (lawful).

Marrying a partner according to taste legally and the dowry is real as a dowry, not just to spill the spurting fluid, not to fulfill lust only, or not to commit adultery. There is a provision to provide compensation (dowry) as an obligation based on the agreement. Of course, this is very different from Sunni marriages that are generally carried out in Indonesia.

M. Quraish Shihab describes the issue of mut'ah marriage in the sense of having fun, enjoying it in an urgent or emergency situation which is declared halal and there are those who equate it with adultery even though the scholars forbid it. It is also mentioned as a misunderstanding because of the deviation of the practice which is categorized as adultery committed in the name of mut'ah marriage, by deliberately changing the requirements to make it halal ${ }^{23}$.

According to Islamic law experts among fuqaha, it is forbidden to practice mut'ah marriage. Among the Shia, they argue that this is allowed because the provision was cancelled. This means that mut'ah marriage has been allowed after it was originally forbidden. The problem that arises among fuqaha is about the law of mut'ah marriage, whether after being allowed to marry in emergency situation during the Khaibar War the law continues to apply until now or it has been cancelled. This is because there are many narrations that say that the Prophet PBUH (after the Khaibar events) had forbidden mut'ah

${ }_{23}$ M. Quraish Shihab, Perempuan dari Cinta Sampai Seks, dari Nikah Mut'ah Sampai Nikah Sunnah, dari Bias Lama sampai Bias Baru, 187. marriage. This creates controversy among the fuqaha, namely those who see this as absolutely haram (forbidden) and those who absolutely allow mut'ah marriage ${ }^{24}$.

According to M. Quraish Shihab, scholars of the Imamiyah Shia madhhab agreed to state the following. Women who are married are women who are mature and reasonable, and free from all obstacles to marriage, such as the prohibition on marrying a mahram either because of heredity or breastfeeding, as well as women who are married, or who are in period of iddah of divorce or death and women who are musyrikah ${ }^{25}$.

In a mut'ah marriage, a woman cannot marry a married man. In the covenant, the clear and agreed time limit for living together must be mentioned. Quraish's opinion about the pillars of mut'ah is the time limit for marriage according to the amount of dowry that must be mentioned. In fact, based on the fatwa of Shia scholars, if they continue to live together after the contract that has been pronounced has ended, then the mut'ah marriage becomes invalid. In mut'ah marriage, there is no husband's obligation to provide sustenance for the woman he married to unless otherwise stipulated in the contract. For men, it is permissible to marry more than four (Sunni) women at the same time. Regarding witnesses, this is not an absolute requirement for a mut'ah marriage to be valid.

According to M. Quraish Shihab, there are privileges of mut'ah marriage. First, the purpose of mut'ah marriage is not to produce offspring. Children's problems do not need to be considered. Second, as long as the wife is young and has not given birth, the divorce has been planned and agreed upon. Third, helping young people to channel their biological needs. Leaving them without channelling or forcing them to wait until they are materially ready can lead them into unlawful acts ${ }^{26}$.

This was stated by Shihab who cited the opinion of Abbas al-Aqqad (1964 AD), an Egyptian Muslim scholar, which was also proposed by Bertrand Russell (1872-1970 AD), a British philosopher. According to Shihab, Al-

\footnotetext{
24 Yanggo dan Hafiz Anshari, Problematika Hukum Islam Kontemporer (Jilid I), (Jakarta: PT. Pustaka Fiirdaus, 1996), 64.

25 M. Quraish Shihab, Op.Cit, 211.

26 Ibid., 205.
} 
Aqqad commented that Islam has provided a way out of this kind of problem for members of the military, namely with mut'ah marriages. It seems that Al-Aqqad's statement is not wrong in analogizing who is doing studies with soldiers who are involved in $\mathrm{war}^{27}$. Lendsy, as chairman of the Court in Denver, proposed 'friendly marriage', but it was rejected by religious leaders and moralists in the army because it was considered to prioritize "the happiness of youth" than instilling a sense of guilt in them.

In reality, if a person is asked, "Do you agree if your daughter is married with mut' ah marriage?" The answer is clearly "No!" Shiite women in Iran are reluctant to be married with mut'ah marriage. Even, Murtadha Muthahhari in his argument mentions that mut'ah is one way to revive the sunnah that has been forgotten/neglected ${ }^{28}$.

Marriage is intended, among others, to achieve sakinah, mawaddah, and rahmat (grace). Mut'ah marriage is impossible to achieve the ideals of marriage because there is no purpose for those all ${ }^{29}$. In the narration of Ibn Tsauban, he said, the Messenger of Allah PBUH said; Whoever the wife asks her husband for divorce for no reason, it is forbidden for her the smell of heaven. This requires both (husband and wife) who are tied with sacred relation (marriage) to be harmonious. Q.S An-Nisa 21 states that “... and she has taken from you a firm commitment". This verse states the rights and obligations of husband and wife that must be fulfilled and instructions regarding intercourse (Q.S. An-Nisa verse 19) ${ }^{30}$. Therefore, in mut'ah marriage, the procedure as prescribed is only a sweetener so that it does not appear that there are deviations from the applicable marriage rules.

The priority in mut'ah marriage is only to enjoy sexual intercourse according to the agreed period. Furthermore, the husband and wife will separate without a divorce because it has been said to be divorced at the determined time. Mut'ah marriage has neglected the intended purpose of marriage or its sunnah, which is long-lasting in nature, even until the end of their life (see Surah Yasin [36]: 56).

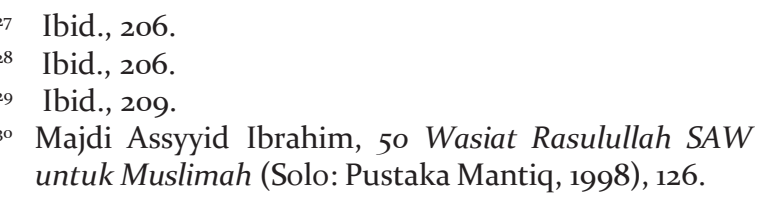

In article 1 (one) of Law No. 1 Year 1974 concerning marriage, it is stated that "Marriage is an inner and outer bond between a man and a woman as husband and wife with the aim of establishing a happy and eternal family (household) based on belief in the Almighty God" ${ }^{31}$.

The example provided by M. Quraish Shihab actually happened in Ali Ibn Yaqthin's family who asked Imam ar-Ridha (the 8th Imam of the Shia madhhab, 770-818 AD) about mut'ah. The grandson of Imam Ja'far ash-Shadiq (the 6th Imam of the Shia madhhab, 699-765 AD) answered: "What is your business with that? Allah has made you not need it (that is because you already have a wife)" 32 .

According to Shihab in another narration, it is stated that Imam Ja'far ash-Shadiq when answering question about mut'ah, he read the word of Allah in QS. An-Nur [24] verse 3, namely "A male fornicator would only marry a female fornicator or idolatress. And a female fornicator would only be married to a fornicator or idolater. This is all forbidden to the believers". On the basis of his answer, the Shia scholars stated that: "Whoever performs mut'ah with a female fornicator, he is a fornicator too". ${ }^{33}$

Fathul Bari and Ibn Hajar Al Asqalani explained that the practice of mut'ah marriage is like a contract marriage in which the law of its legitimation has been mansukh or erased.

Ar-Rabi 'bin Sabrah Al-Juhani said that his father told him that the Messenger of Allah said, "O people, I used to allow you to marry mut'ah. Know that Allah SWT has forbidden it until the Day of Resurrection." (Hadith narrated by Muslim). Based on this, the scholars of all madhhab agree that mut'ah marriage is haram (unlawful). They classify this type of marriage as a marriage that has a serious impact as well as a threat to the state. The Prophet's companion, Umar bin Khattab, considered mut'ah marriage as an evil. In addition, the perpetrator is threatened with stoning because it is no different from adultery.

The basis of the practice of mut'ah namely being considered an emergency is clearly contrary to Islamic law in Indonesia. The aim and purpose

\footnotetext{
${ }^{31}$ Undang-Undang No. 1 Tahun 1974 Tentang Perkawinan (Republik Indonesia, 1974).

32 M. Quraish Shihab, Op.Cit., 210.

33 Ibid., 211.
} 
of marriage is permanent and does not conflict with Islamic teachings. Mut'ah actually destroys human civilization and ethics or implies bad intentions, especially for women. The impact of mut'ah will befall the offspring. Mut'ah marriage will cause dirty disease and the children are born without legal certainty. This is because the children are the children of an illegitimate relationship.

By prohibiting mut'ah marriage, this will reduce the immoral space. Therefore, the government should take firm steps against the practice of mut'ah marriage that occurs in several regions in Indonesia. This is because it is a disguised prostitution that prioritizes lust and material gain. In practice, mut'ah is seen as degrading the dignity of women and the children who are born have no clear status. Mut'ah is contrary to the basic provisions of the Bill of Material Law of the Religious Courts on Marriage in article 39 which state that every perpetrator of a mut'ah marriage shall be sentenced to imprisonment for a maximum of 3 (three) years and the marriage is null and void by law. ${ }^{34}$

\section{E. Not Islamic Teachings}

Marriage is family ties so it must be realized that women in Islam are very guarded for their nature (honor) because they are the pillars of consumptive life. Today's society does not realize that the potential of women is weakened even though there is a strong nobility.

Mut'ah marriage leads to the source of the form of liberation from the ongoing lust. This destroys the fitrah (nature) and morality and contradicts His sharia as a whole. If it is studied thoroughly, the relationship of a man and a woman who are gathered in the form of a family community will be described as a family that is able to live and fulfill His commands perfectly. ${ }^{35}$

The honor of women is broken down from the procedures for seeing, asking for permission, opening and covering aurat (body parts required to be covered), the journey of women, the return of the man (husband) to the house, to the position in the midst of her relatives.

The responsibility of men to women is to find

\footnotetext{
34 Norma Fajria Nida, "Analisis Terhadap Hukum Nikah Mut'ah Menurut M. Quraish Shihab” (Universitas Islam Negeri Walisongo Semarang, 2018), 89.

35 Muhammad Alghazali, Bukan Ajaran Islam (Solo: Pustaka Mantiq, 1995), 185.
}

peace as the person in charge of the family. Q.S. Al-Qasas Verse 25 implies that the household is a place to express feelings in order to get peace because the role of a husband is to protect his wife and children.

Most people think that ending a marriage and letting their biological instincts mess up is fine until they are able to pay a high dowry. This means that bad habits are maintained rather than getting used to living with religious rules. Therefore, it is not wrong when biological instincts are channeled using religious rhythms. To overcome this, it is necessary to establish a family and educate children who need the community, especially legal couples.

\section{CONCLUSION}

First, if the logic of mut'ah is only immoral, the legitimation of mut'ah to be accepted as a marriage that is a very urgent need or even a mere emergency actually degrades human dignity. Meanwhile, the children who are born do not have legal certainty;

Second, tafsir (interpretation) experts emphasize the importance of the maudu' $i$ (thematic) interpretation method, especially regarding mut'ah which can be explained thoroughly because it will be easier to draw conclusions that are concentrated on the subject that mut'ah is equated with fasting for people who have sharia reasons and prayer that can performed in jama and qasar;

Third, mut'ah only because of an emergency is a reason to seek justification that is forced and contrary to Islamic law in Indonesia. The Compilation of Islamic Law emphasizes that marriage is eternal in nature in order to establish a sakinah, mawaddah and rahmah family;

Fourth, mut'ah marriage is contrary to the basic provisions of the Material Law on Marriage. This is because it is strictly prohibited to marry mut'ah. According to Article 2 paragraph 2 of Law No. 1 Year 1974 concerning marriage, it is explained that every person who gets married who is not registered with the authorized official (Office of Religious Affairs or civil registry) to obtain a marriage certificate in order to obtain legal certainty is considered to have violated the law because it injures the sacred meaning and purpose of marriage. In the book entitled "Compilation of 
Islamic Law" it is expressly stated that mut'ah marriage is unlawful. In paragraph 143 of the Bill of Material Law of the Religious Courts on Marriage Year $2007^{36}$ article 5 paragraph 1, it is stated that marriages that are not registered by Office of Religious Affairs officials are subject to a maximum fine of IDR 6,000,000 (six million rupiah) or imprisonment for a maximum of 6 (six) months.

Mut'ah marriages are not only carried out by foreign nationals and are not recorded. There is even an element of intent not to register with the authorized officials (Office of Religious Affairs) so as to obscure the evidence of the marriage even though the ceremony is led by a religious leader or local community leader. Such procedures are certainly contrary to the marriage law or can cause new problems where the marriage seems to be lawful, but the parties can be considered not to understand the consequences of their actions.

In the Bill of Material Law of the Religious Courts on Marriage, it is expressly stated that the prohibition on mut'ah in Article 39 states that every perpetrator of a mut'ah marriage shall be sentenced to imprisonment for a maximum of 3 (three) years and the marriage is null and void by law. Mut'ah marriage overrides all applicable laws and regulations.

\section{SUGGESTION}

The issue of mut'ah marriage should not be colored by practical politics which cause deviations from religious arguments. There needs to be an improvement in morality and aqidah in this matter. As a matter of fact, the foundation of the Sunni scholars remains a reference to act for the sake of upholding religion as an essential rule.

Therefore, scholars should not be led to a practical political agenda, but still discuss knowledge whose direction is essential on mut'ah so that the prohibition can be applied and mut'ah marriage can be punished by law. Although, in reality, there have never been any legal complaints from women or witnesses.

\footnotetext{
${ }^{36}$ Ardian Kurniawan, "Sanksi Pidana Pelanggaran Pencatatan dan Relevansinya Dalam Perkembangan Hukum Perkawinan di Indonesia" (Universitas Islam Negeri Sulthan Thaha Saifuddin Jambi, 2020), 10.
}

\section{ACKNOWLEDGMENT}

The researchers would like to express gratitude to the parties who have provided moral and material support so that this article can be published.

\section{BIBLIOGRAPHY}

Al-Hafid, Ibnu Rusyd. Bidayat al-Mujtahid wa Nihayah al-Muqtashid (terjemahan) (Juz I). Kairo: Maktabah Dar al-Salam, 1999. 187665 .

Al-khatib, Syaikh Muhammad al-Syarbini. alIqna (Juz II). Beirut: Dar al-Fikr, 2005. 409.

Ali Akhbar Abaib Mas Rabbani Lubis. "NIKAH MUTAH: Melirik Pergumulan Sejarah, Firman, Sabda, dan Nalar Nikah Mutah." Jurnal Universum 14, no. 1 (2020): 6.

At-Tirmidzi, Muhammad bin Isa bin Saurah. Hadis No. 1024 dalam CD program Mausu'ah Hadis al-Syarif. Riyad: VCR II Global Islamic Software Company, 1997. 1.

Aulia, Tim Redaksi Nuansa, Kompilasi Hukum Islam Ed. Lengkap. Bandung: Nuansa Aulia, 2020. 1.

Dahlan, Abdul Aziz, dan dkk. Ensiklopedia Hukum Islam (Jilid IV). Jakarta: Ichtiar Baru Van Hoeve, 1996. 1346.

Indonesia, Republik. Undang-Undang Tentang Perkawinan, 1974.

Kurniawan, Ardian. "Sanksi Pidana Pelanggaran Pencatatan dan Relevansinya Dalam Perkembangan Hukum Perkawinan di Indonesia.” Universitas Islam Negeri Sulthan Thaha Saifuddin Jambi, 2020. 10.

M. Quraish Shihab. Perempuan dari Cinta Sampai Seks, dari Nikah Mut'ah Sampai Nikah Sunnah, dari Bias Lama sampai Bias Baru. Jakarta: Lentera Hati, 2016. 187-211.

Majdi Assyyid Ibrahim. 50 Wasiat Rasulullah SAW untuk Muslimah. Solo: Pustaka Mantiq, 1998. 126.

Muchtar, Karnal. Asas-Asas Hukum Islam Tentang Perkawinan. Jakarta: Bulan Bintang, 1996. 1.

Muhammad Alghazali. Bukan Ajaran Islam. Solo: Pustaka Mantiq, 1995. 185. 
Muhammad Anis Malik. "Wawasan Hadis Tentang Nikah Mut'ah (Suatu Kajian Mawudhu'iy)." Jurnal Al-Maiyyah 8, no. 2 (2015): 285.

Muhammad Fu'ad Syakir. Zawajun Bathil: alMisyar, al-Urfi, as-Sirri, al-Mut'ah, Terj. Fauzun Jamal dan Alimin, "Nikah Terlarang: al-Misyar, al-Urfi, as-Sirri, al-Mut'ah." Jakarta: CV. Cendikia Sentra Muslim, 2002. 65.

Murata, Sachiko. Temporary Marriage in Islamic Law (Terjemahan Tro Wibowo Budi Santoso: Lebih Jelas Tentang Mut'ah Perdebatan Sunni dan Syi'ah. Jakarta: PT. Raja Grafindo Persada, 2001. 44-50.

Norma Fajria Nida. "Analisis Terhadap Hukum Nikah Mut'ah Menurut M. Quraish Shihab." Universitas Islam Negeri. Walisongo Semarang, 2018. 89.

Nurlailiyah Aidatussholihah. "Kawin Kontrak di Kawasan Puncak : Antara Normatif, Yuridis, dan Realita." Jurnal Al-Ahwal 5, no. 2 (2012): 3 .

Sayuti Thalib. Hukum Kekeluargaan Indonesia (Cet. 5). Jakarta: UI Press, 1978. 47.

Sayyid Sabiq. Fikih Sunnah (Jilid 6) Terj. Mohammad Thalib. Bandung: PT. al-Ma'arif, 1980. 63.

Fiqh al-Sunnah (Juz II). Kairo: Maktabah Dar al-Turas, 1970. 130.

Yanggo, Chuzaimah T, dan Hafiz Anshari. Problematika Hukum Islam Kontemporer (Jilid I). Jakarta: PT. Pustaka Firdaus, 1996. 64-85.

Zahry Hamid. Pokok-Pokok Hukum Perkawinan Islam dan Undang-Undang Perkawinan di Indonesia. Yogyakarta: Bina Cipta, 1978. 
HALAMAN KOSONG

408 Jurnal Penelitian Hukum De Jure Vol. 21 No. 3, September 2021: 397-408 